\title{
An interpolation method for stream habitat assessments with reference to the crystal darter
}

\author{
Kenneth Richard Sheehan \\ West Virginia University
}

Follow this and additional works at: https://researchrepository.wvu.edu/etd

\section{Recommended Citation}

Sheehan, Kenneth Richard, "An interpolation method for stream habitat assessments with reference to the crystal darter" (2006). Graduate Theses, Dissertations, and Problem Reports. 2482.

https://researchrepository.wvu.edu/etd/2482

This Thesis is protected by copyright and/or related rights. It has been brought to you by the The Research Repository @ WVU with permission from the rights-holder(s). You are free to use this Thesis in any way that is permitted by the copyright and related rights legislation that applies to your use. For other uses you must obtain permission from the rights-holder(s) directly, unless additional rights are indicated by a Creative Commons license in the record and/ or on the work itself. This Thesis has been accepted for inclusion in WVU Graduate Theses, Dissertations, and Problem Reports collection by an authorized administrator of The Research Repository @ WVU. For more information, please contact researchrepository@mail.wvu.edu. 
AN INTERPOLATION METHOD FOR STREAM HABITAT ASSESSMENTS WITH REFERENCE TO THE CRYSTAL DARTER

\author{
Kenneth Richard Sheehan \\ Thesis submitted to the \\ Davis College of Agriculture, Forestry and Consumer Sciences \\ at West Virginia University \\ in partial fulfillment of the requirements \\ for the degree of \\ Master of Science \\ in \\ Wildlife and Fisheries Resources \\ Stuart A. Welsh Ph.D., Chair \\ J. Steven Kite Ph.D. \\ Michael P. Strager Ph.D.
}

Division of Forestry

Morgantown, WV

2006

Keywords: Interpolation, Natural Neighbor, Aquatic Habitat Modeling, Kriging, Habitat Assessment

Copyright 2006 Kenneth R. Sheehan 


\title{
AN INTERPOLATION METHOD FOR STREAM HABITAT ASSESSMENTS WITH REFERENCE TO THE CRYSTAL DARTER
}

\begin{abstract}
Kenneth R. Sheehan

Crystallaria asprella spp. (Elk River crystal darter) is documented only in Elk River, West Virginia. Little life history detail is known about this lotic, benthic-dependent species. Previous studies have led to a very basic understanding of the use of depth, flow and substrate of the crystal darter (Crystallaria asprella), and less is known about the Elk River crystal darter. Due to substrate-specificity in crystal darters (which reportedly bury in sand), a study concerning benthic stream habitat modeling was undertaken. Substrate and depth modeling using $>5 \%$ of an area sampled at a resolution of $0.093 \mathrm{~m}^{2}$ square spatial data in a Geographic Information System (GIS) was theorized possible. Representation of actual substrate using $22680.093 \mathrm{~m}^{2}$ data cells with UTM coordinates was created in ESRI ArcMap version 9.1. Each cell signified the dominant substrate type found in that area. We selected points representing 5\% and $2.5 \%$ percent of the site area for both depth and substrate and natural neighbor interpolations were run on these points. The actual values of depth and substrate were compared with predicted values to determine accuracy of interpolated data. The 5\% interpolations were more accurate for both depth and substrate than $2.5 \%$ sampling results. The $2.5 \%$ interpolations achieved accuracy up to $92 \%$ of actual values and interpolations based on $5 \%$ within $5 \%$ of actual when comparing area of substrate predicted. Depth predictions based on $2.5 \%$ attained accuracy from $49 \%$ to $92 \%$ when applied to threshold values while 5\% percent interpolations illustrated accuracy levels ranged from $57 \%$ to $95 \%$ for the same thresholds. Our findings demonstrate the use of minimal amounts of fine-scale data of substrate and depth for interpolation of habitat in large areas of a stream channel. This approach allows time and cost saving options for sufficiently accurate microhabitat scale habitat assessments of large sections of rivers, and provides functional maps to aid habitat-based fisheries management.
\end{abstract}




\section{DEDICATION}

Thanks family, friends, and colleagues! Reality aside (no this is not sarcastic), it's been a wonderful ride. 


\section{ACKNOWLEDGEMENTS}

I would like to thank R. Utz, G. Staines, and your mom for numerous scientific conversations and idea sessions. Thanks as well to Pat Mazik for meeting with me initially and letting me join the coop (as well as funding). Kyle Hartman, thanks for the use of the computer in the GIS lab, without which, I wouldn't have been able to finish this thesis. 


\section{TABLE OF CONTENTS}

ABSTRACT

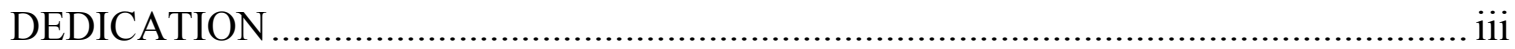

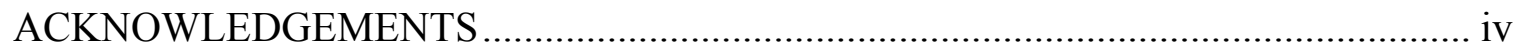

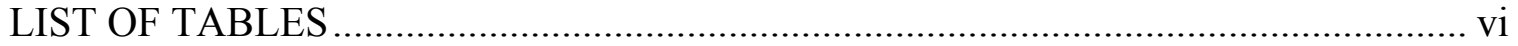

LIST OF FIGURES …................................................................................... vii

CHAPTER 1: Literature Review .......................................................................... 1

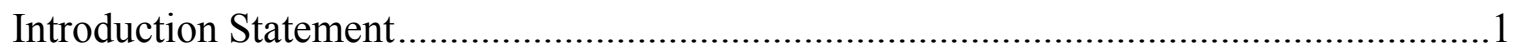

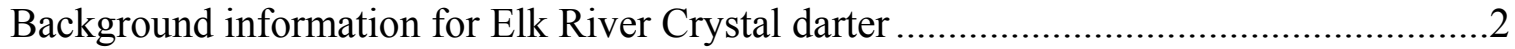

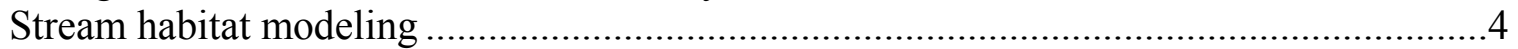

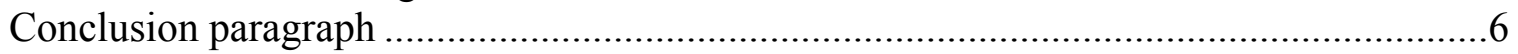

Literature Cited ............................................................................................. 7

CHAPTER 2: An interpolation method for stream habitat assessment with reference to

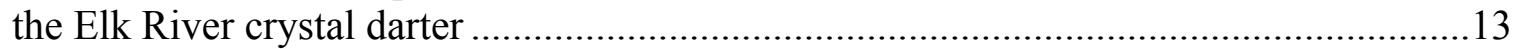

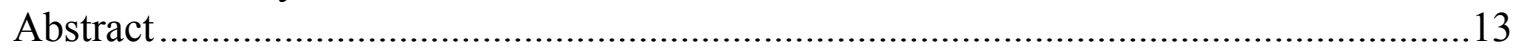

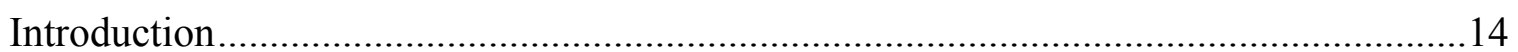

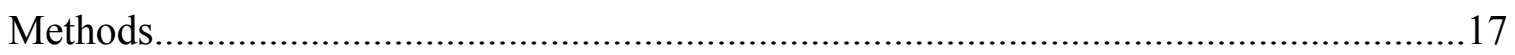

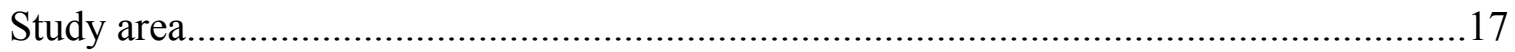

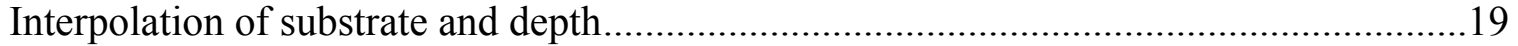

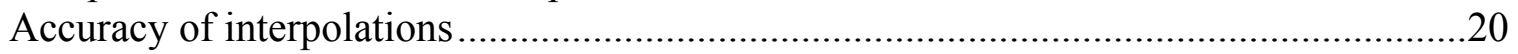

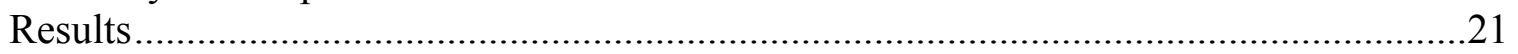

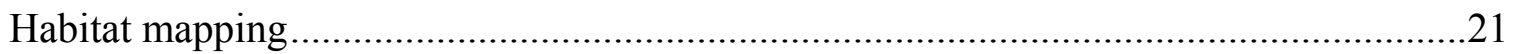

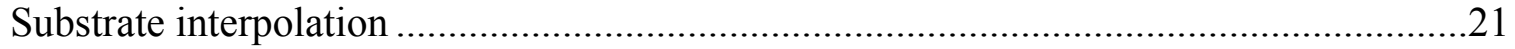

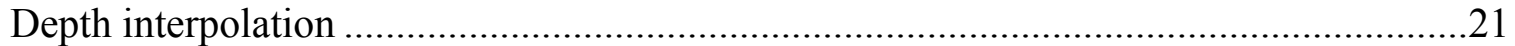

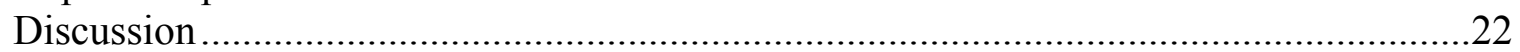

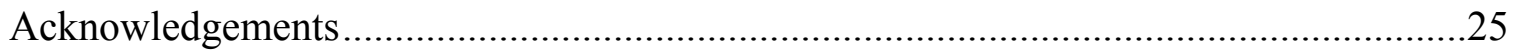

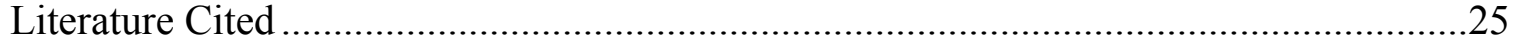

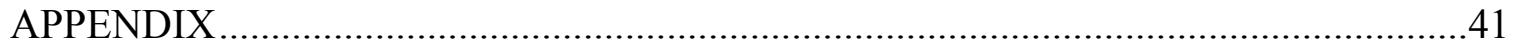




\section{LIST OF TABLES}

Table 1. USDA soil survey manual substrate size delineations used as guideline for substrate classification (Soil Survey

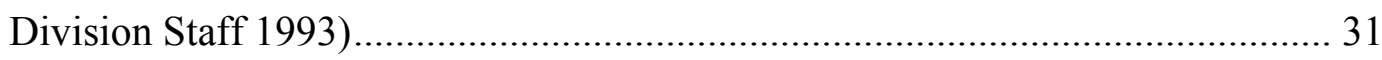

Table 2. Substrate root mean square error values of complete substrate based on actual values .

Table 3. Depth interpolation root mean square errors based on complete depth (actual values), $5 \%$ interpolations and $2.5 \%$ interpolations. 


\section{LIST OF FIGURES}

Figure 1. Simple flow chart containing general overview of data collection and interpolation process

Figure 2. Substrate raster interpolation maps comparing actual (known) values to interpolations based on $5 \%(\mathrm{~A})$ and $2.5 \%(\mathrm{~B})$ of actual values .36

Figure 3. Depth raster interpolation maps comparing actual (known) values to interpolations based on 5\% (A) and 2.5\% (B) of actual values

Figure 4. Natural neighbor substrate interpolations based on actual (2268 points.), $5 \%$ of actual values (A; 113 points), and $2.5 \%$ of actual values (B; 56 points) .38

Figure 5. Depth Percent match of interpolation A (based on 5\% of actual values) and B (based on $2.5 \%$ of actual values) when compared to initial actual values

Figure 6. Depth interpolation matching (all) exact depth values within 5,10 and $20 \%$ thresholds $(5 \%$ threshold $=\%$ depth values within $3 \mathrm{~cm}$ of actual values) 


\section{CHAPTER 1: Literature Review}

\section{Introduction statement}

Little is known about the Elk River crystal darter (Crystallaria asprella spp.), a rare species that is known from 12 specimens collected during 1980-2005 (Cincotta and Hoeft 1987, Osier 2005, Warren et al. 2000). The objectives of this research were to document movement and habitat use of the Elk River crystal darter, but the inability to capture specimens hindered my research efforts. Researchers have targeted Elk River crystal darters with multiple capture gears including snorkeling, straight seines, bag seines, trawls, boat electrofishers, backpack electrofishers, and parallel wires electrofishers. Of these gears, straight seines, bag seines, and boat electrofishers were successful, but with an extremely low catch per unit effort that indicates either a small population or an inefficiency of gear types. Consequently, I designed a small fyke net for use in medium sized rivers to try a different gear type. Fyke nets were fished in riffle, glide, and head of pool habitats during expected crepuscular and night movements of crystal darters from pool to riffle habitats. These movements were suggested for other populations of crystal darter (Grandmaison et al. 2003, Osier 2005, Hatch 1997). The fyke net sampling did not capture crystal darters, and results of its effectiveness on capturing other species will be reported separately. I was also interested in habitat use of the Elk River crystal darter, but only captured two individuals via 50 foot bag seine during my study. Consequently, I refocused my efforts toward developing a computerbased interpolation method of modeling stream habitat. The modeling approach was applied to data from a small stream, but should be applicable to larger rivers due to similar depositional processes across scales, such as the Elk River, and allows 
researchers to accurately estimate stream habitat from a small sample of data points. Further, the habitat modeling method allows researchers to predict the amount of available habitat for a given species given previous knowledge of habitat use requirements.

\section{Background information for Elk River Crystal darter}

The Elk River crystal darter is a rare fish currently limited to several pool and riffle locations in a $30 \mathrm{~km}$ stretch in Elk River, West Virginia between Sutton Reservoir and Charleston, WV (Cincotta and Hoeft 1987, Osier 2005). Currently C. asprella populations persist in Ohio, Missouri and Mississippi drainages though population numbers have declined. Crystallaria asprella is considered extirpated from other Ohio river drainage states Tennessee, Illinois, Indiana, Kentucky and Ohio (Cincotta and Hoeft 1987). Abundance is unknown due to lack of consistent capture. Sampling gear vulnerability of C. asprella and C. asprella spp. is minimal (Osier 2005, Grandmaison et al. 2003). A total of twelve Elk River crystal darters have been collected since 1980 in the Elk River drainage and the Elk River crystal darter is recognized as a vulnerable species (Warren et al. 2000). The four most recent individuals were collected two each in summer 2003 and summer 2005.

Crystal darters were originally described as Pleurolepsis asprellus (Jordan 1878). There is general agreement crystal darters fit into the monophyletic group of all darters and there is no current documentation indicating C. asprella ssp. falls outside this group. This darter group is further delineated into quad-generic classification between Ammocrypta, Crystallaria, Etheostoma and Percina. In 1897, Jordan reclassified the fish as Ammocrypta asprella which it remained for 94 years (Page 1981). Page (1981) used 
the presence of 12-15 dorsal spines and 13-14 dorsal rays as evidence for recognizing the genus Crystallaria.

The Elk River crystal darter population is an evolutionary significant unit (Wood and Raley 2000, Morrison et al. 2006) originating from C. asprella stock whose historic range spanned from West Virginia, west to Missouri, and from Minnesota south to the Gulf of Mexico (Page 1980, Keuhne and Barbour 1983, Grandmaison et al. 2003). Genetic analysis has shown Elk River C. asprella differs 10-12\% in mitochondrial DNA sampling of the cytochrome $b$ gene in comparison to other crystal darter populations (Wood and Raley 2000, Morrison et al. 2006). Recent close examination of C. asprella spp. genetic variation from other crystal darter populations has yielded similar results and recommendations (Morrison et al. 2006). This size of the genetic divergence has prompted suggested listing of the Elk River population as either a subspecies or new species of Crystallaria (Wood and Raley 2000, Osier 2005, Morrison et al. 2006). Warren et al. (2000) recognized the Elk River crystal darter as a subspecies. Future work in phylogeography, an emerging field explaining genetic lineage with emphasis on geographic location, may indicate the recent evolutionary ancestor of the Elk River crystal darter (Waters et al. 2001).

Little is known about life history and habitat use of the Elk River crystal darter in part due to difficulty in collection and sampling of large river benthic habitat and limited field season (George et al. 1996, Osier 2005). The Elk River crystal darter is thought to follow habitat use of other C. asprella. Typical collection depths of other C. asprella range from $0.5-2.0$ meters. The fish are rarely collected in velocities less than $32 \mathrm{~cm} / \mathrm{sec}$ (George et al. 1996, Osier 2005) which seems to indicate lower flow velocity preferences. 
Elk River specimens have been caught over predominantly gravel substrate intermixed with boulders and sand patches (Cincotta and Hoeft 1987, Osier 2005). It is believed to mirror observed Crystallaria species behavior pattern of burying in sand (Miller and Robinson 1973). Due to capture specimen size typically in the range of $80-100 \mathrm{~mm}$, life span is assumed to be similar to other Crystallaria with a life cycle of two years on average (Hatch 1997). Elk River crystal darters are closely associated with Ammocrypta pellucida, the eastern sand darter, though less translucent, more completely scaled and larger in size (Simons 1996).

There have been concerted efforts by E. Osier and S. Welsh with extensive bag seine episodes over a two year period spanning summers of 2003 and 2004. During this time period only two specimens were captured at the site in the town of Clendenin, WV (Osier 2005). Dan Cincotta a biologist in the WV Department of Natural Resources has conducted annual samplings of the Elk River with no additional specimen captures.

\section{Stream habitat modeling}

Stream river habitat is often viewed as a heterogeneous complexity of water currents, water depths, and rock sizes (Bain and Stevenson 1999, Rosgen 1996, Knighton 1998, Komar and Carling 1991, Leopold and Maddock 1953). Although many components contribute to stream habitat, researchers often view water current, water depth, and rock size as components perceived by fish as important (Kohler and Hubert 1999, Bain and Stevenson 1999, Arend 1999). In some smaller streams, habitat is relatively simple to measure, owing in part to accessibility, but larger streams pose difficulties in habitat assessment owing to the time it takes to survey larger areas and inaccessible areas of fast and deep waters. Stream habitat modeling, a computer-based 
approach to estimating habitat, is a method that overcomes some of the difficulties with habitat assessments in larger rivers.

The predictability of stream habitat components allows one to effectively model habitats (Armstrong 2000). Stream habitats are predictable owing to patterns in particle size deposition relative to water current velocities (Smith and Ferguson 1995, Keller 1971, Knighton 1998). Substrate, velocity, and depths of stream habitats are structured at map scales, such as riffle/pool sequences (Leopold and Maddock 1953, Powell 1998) and microhabitat scales, such as rock size sorting (Komar and Carling 1991), and velocity-controlled depositional areas with abrupt substrate transitions (Smith and Ferguson 1995, Ferguson 2003). Results indicate the spatially-correlated structure of stream habitats promotes highly predictable and accurate interpolations of substrate and depth data.

With the advance of computer technologies, researchers have the opportunity to interpolate or estimate measurements within a geographic area based on a sample of data points of the area of interest (Fisher and Rahel 2004). Interpolation methods are used in many diverse fields of science, including forestry (He et al. 2000), ornithology (Dettmers and Bart 1999), medical science (Vine et al. 1997), weed science (Zille et al. 2002) and fisheries (Toepfer et al. 2000). Several types of interpolation approaches are available, each one with specific applications, including nearest-neighbor, ordinary kriging, inverse distance weighted (IDW), pointinterp (similar to IDW), spline (which minimizes surface curvature), and combinations thereof (co-kriging). Some methods of kriging may be manipulated to account for directional weighting, i.e. when downstream is oriented on the geographic plane, it is possible to "weight" interpolations accordingly. 
Sand patches, often have a specific shape and edge boundary (Smith and Ferguson 1995, Ferguson 2003) and are a good example of directional weighting in nature. Search radius may also be altered, which allows interpolation to react to a variety of spatial scales.

We initially entertained using ordinary kriging, IDW, or nearest (natural) neighbor $(\mathrm{NN})$ interpolations for this project. Inverse disatance weight interpolation has often been compared to ordinary kriging (Meuller et al. 2004, Tabios and Salas 1985, Kravchenko and Bullock 1999, Zimmerman et al. 1999, Zille et al. 2002). Results of prior studies indicate both methods have promise, but which performs better is still a point of contention and seems to depend on validation method and type of data being interpolated (Meuller et al. 2004). The IDW method is not as good at interpolating data with spatial qualities as other methods (Meuller et al. 2004). The NN interpolation method is appropriate for stream habitat because predicted values of cells are heavilyinfluenced by values of adjacent cells (Sibson 1981). In streams, habitat structuring produces differentially-sized patches of specific habitat types (Boyero 2003), so that two samples of habitat within adjacent areas of a small area are likely to be similar or spatially correlated. Spatial autocorrelation is a concern for some spatial studies (Liebhold and Gurevitch 2002), but is an important component that contributes to predictability and accuracy in habitat interpolation methods (Robertson 1987).

\section{Conclusion paragraph}

This chapter reviewed literature relative to the Elk River crystal darter and stream habitat modeling. Little is known about the Elk River crystal darter, including a lack of knowledge about the use and availability of habitat in the Elk River. Quantifying habitat availability for long sections of large rivers, such as the Elk River, has previously 
been cost-inhibited. In Chapter 2, we provide a method to interpolate stream habitat and create accurate maps of river habitat using minimal real world spatial data. Although the habitat interpolation methods were developed on a small stream, we believe that the methods will apply to larger systems, and further research efforts will focus on applying these methods toward habitat interpolation in Elk River, West Virginia.

\section{Literature Cited}

Armstrong, M.P. 2000. Geography and computational science. Annals of the Association of American Geographers 90:146-156.

Arend, K.K. 1999. Classification of streams and reaches. Pages 57-74 in M.B. Bain, and N.J. Stevenson, editors. Aquatic habitat assessment: common methods. American Fisheries Society, Bethesda, Maryland.

Bain, M.B. and N.J. Stevenenson, editors. 1999. Aquatic habitat assessment: common methods. American Fisheries Society, Bethesda, Maryland.

Boyero, L. 2003. The quantification of local substrate heterogeneity in streams and its significance for macroinvertebrate assemblages. Hydrobiologia 499:161-168.

Cincotta, D. A. and M.E. Hoeft. 1987. Rediscovery of the crystal darter, Ammocrypta asprella in the Ohio River Basin. Brimelyana 13:133-136.

Dettmers, R. and J. Bart. 1999. A GIS modeling method applied to predicting forest songbird habitat. Ecological Applications 9:152-163.

Etnier, D.A. and W.C. Starnes. 1993. The fishes of Tennessee. University of Tennessee Press, Knoxville. 
Ferguson, R.I. 2003. Emergence of abrupt gravel to sand transitions along rivers through sorting processes. Geological Society of America 31:159-162.

Fisher, W.L. and F.J. Rahel, editors. 2004. Geographic information systems in fisheries. American Fisheries Society, Bethesda, Maryland.

George, S. G. W. T. Slack, and N. H. Douglas. 1996. Demography, habitat, reproduction and sexual dimorphism of the crystal darter, Crystallaria asprella (Jordan), from southcentral Arkansas. Copeia 1996:68-78.

Grandmaison, D., J. Mayasich, and D. Etnier. 2003. Crystal darter status assessment report. U. S. Fish and Wildlife Service. Technical Report \# NRRI/TR-2003/19. $<$ http://midwest.fws.gov/endangered/fishes/crda-sa.pdf $>$ (18 August 2004)

Hatch, J.T. 1997. Resource utilization and life history of the crystal darter, Crystallaria asprella (Jordan), in the lower Mississippi River, Minnesota. Minnesota Natural Heritage and Nongame Wildlife Research Program, Minnesota Department of Natural Resources. St. Paul, Minnesota.

He, H. S. D. J. Madenoff, T. A. Sickley, and G. G. Guntenspergen. 2000. GIS interpolations of witness tree records (1839-1866) for northern Wisconsin at multiple scales. Journal of Biogeography 27:1031-1042.

Jenkins, R.E. and N.M. Burkhead. 1993. Freshwater fishes of Virginia. American Fisheries Society, Bethesda, Maryland.

Jordan, D. S. 1878. A catalogue of fishes of Illinois. Illinois Natural Historical Bulletin 2: 37-70.

Keller, E.A. 1971. Areal sorting of bed-load material: The hypothesis of velocity reversal: Geological Society of America Bulletin 82:753-756. 
Keuhne, R. A. and R.W. Barbour. 1983. The American darters. University Press of Kentucky, Lexington.

Knighton, D. 1998. Fluvial forms and processes: a new perspective. Oxford University Press, Great Britain.

Kohler, C.C. and W.A. Hubert, editors. 1999. Inland fisheries management in North America. American Fisheries Society, Bethesda, Maryland.

Komar, P.D. and P.A. Carling. 1991. Grain sorting in gravel-bed streams and the choices of particle sizes for flow-competence evaluations. Sedimentology 38:489-502.

Kravchenko, A. and D.G. Bullock. 1999. A comparative study of interpolation methods for mapping soil properties. Agrononomy Journal 91:393-400.

Liebhold, A.M. and J. Gurevitch. 2002. Integrating the statistical analysis of spatial data in ecology. Ecography 25:553-557.

Leopold, L.B. and T. Maddock. 1953. The hydraulic geometry of stream channels and some physiographic implications. Unites States Geological Survey Professional Paper 252.

Mueller, T.G., N. B. Pusuluri, K. K. Mathias, P. L. Cornelius, R. I. Barnhisel, and S. A. Shearer. 2004. Map quality for ordinary kriging and inverse distance weighted interpolation. Soil Science Society of America Journal 68:2042-2047.

Miller, R.J. and Robinson, H.W. 1973. The fishes of Oklahoma. Oklahoma State University Press, Stillwater. 
Morrison, C.L., D.P Lemarle, D. Wood, T.L. King. 2006. Phylogeographic analyses suggest multiple lineages of Crystallaria asprella (Percidaie: Etheostominae). Conservation Genetics 7:129-147.

Osier, E. 2005. Habitat use and behavior of crystal and spotted darters in the Elk River, West Virginia. Master's Thesis. West Virginia University, Morgantown, West Virginia.

Page, L.M. 1981. Ammocrypta asprella (Jordan), crystal darter. Page 651 in D.S. Lee, C.R. Gilbert, C.H. Hocutt, R.E. Jenkins, D.E. McAllister, and J.R. Stauffer, editors. Atlas of North American freshwater fishes. North Carolina State Museum of Natural History, Raleigh, North Carolina.

Powell, D.M. 1998. Patterns and processes of sediment sorting in gravel-bed rivers. Progress in Physical Geography 22:1-32.

Robertson, G P. 1987. Geostatistics in ecology: Interpolating with known variance. Ecology 68:744-748.

Rosgen, D. 1996. Applied river morphology. Wildland Hydrology, Pagosa Springs, Colorado.

Sibson, R. 1981. A brief description of natural neighbour interpolation. Pages 21-36 in V. Barnett, editor. Interpreting multivariate data. John Wiley \& Sons, New York.

Simons, A. 1991. Phylogenetic relationships of the crystal darter, Crystallaria asprella (Teleostei: Percidae). Copeia 1991:927-936.

Smith, G.H. and R.I. Ferguson. 1995. The gravel-sand transition along river channels. Journal of Sedimentary Research A65:423-430. 
Tabios, G.Q. and J.D. Salas. 1985. A comparative analysis of techniques for spatial interpolation of precipitation. Water Resource Bulletin 21:365-380.

Toepfer, C.S., W.L. Fisher, and W.D. Warde, 2000. A multistage approach to estimate fish abundance in streams using geographic information systems. North American Journal of Fisheries Management 20:634-645.

Vine, M.F., D. Degnan, and C. Hanchette. 1997. Geographic information systems: their use in environmental epidemiologic research. Environmental Health Perspectives 105:598-605.

Warren Jr. M.L., B.M Burr, S.J. Walsh, H.L. Bart Jr., R.C. Cashner, D.A. Etnier, B.J. Freeman, B.R. Kuhajda, R.L. Mayden, H.W. Robison. S.T. Ross, and W.C. Starnes. 2000. Diversity, distribution, and conservation status of the native freshwater fishes of the southern United States. Fisheries 25:7-27.

Waters, J.M. D. Craw, J.H. Youngson, G.P. Wallis. 2001. Genes meet geology: fish phylogeographic pattern reflects ancient, rather than modern, drainage connections. Evolution. 55:1844-1851

Wood, R.M. and M.E. Raley. Cytochrome b sequence variation in the crystal darter Crystallaria asprella (actinopterygii; Percidae). Copeia 2000:20-26

You, J., K. G. Hubbard, and S. Goddard. 2004 (submitted). Comparison of air temperature estimates from spatial regression and inverse distance method. Journal of Atmospheric Oceanic Techniques.

Zille, J.A. M. Milner, J.J. Groeteke. D.A. Mortensen, and M.M. Williams II. 2002. How good is your weed map? A comparison of spatial interpolators. Weed Science $51: 44-55$. 
Zimmerman, D., C. Pavlick, A. Ruggles, and M.P. Armstrong. 1999. An experimental comparison of ordinary and universal kriging and inverse distance weighting. Mathematical Geology 31:375-390. 
Chapter 2: An interpolation method for stream habitat assessments with reference to the Elk River crystal darter

\begin{abstract}
Data interpolation methods for habitat assessments reduce time and labor costs by using a small number of habitat samples to predict habitat of larger areas. The spatial correlation of stream habitat variables, such as substrate and depth, improves accuracy of interpolated data. Using a GIS (ArcMap version 9.1), nearest neighbor interpolation was used to predict substrate and depth (based on $2.5 \%$ and $5.0 \%$ of the total area) within a $210.7 \mathrm{~m}^{2}$ section of a second order stream. The true values of depth and substrate were quantified for the entire study site and compared with predicted values to determine accuracy of interpolated data. The 5\% interpolations were more accurate for both depth and substrate than $2.5 \%$ sampling results. The $2.5 \%$ interpolations achieved accuracy up to $92 \%$ of actual values and interpolations based on 5\% within 5\% of actual when comparing area of substrate predicted. Depth predictions based on $2.5 \%$ attained accuracy from $49 \%$ to $92 \%$ when applied to threshold values while 5\% percent interpolations illustrated accuracy levels ranged from $57 \%$ to $95 \%$ for the same thresholds. Our findings demonstrate the use of minimal amounts of fine-scale data of substrate and depth for interpolation of habitat in large areas of a stream channel. This approach allows time and cost saving options for accurate microhabitat scale habitat assessments of large sections of rivers, and provides functional maps to aid habitat-based fisheries management.
\end{abstract}




\section{Introduction}

The measurement of habitat is central to the management and conservation of fishes (Bain and Stevenson 1999, Murphy and Willis 1999, Noss et al. 1997). Substrate type, water depth, and water current velocity are often considered as important stream habitat variables in both ecology (Gorman and Karr 1978) and fluvial geomorphology (Knighton 1998) and are often collected at fine (i.e., microhabitat) scales in ecological studies, such as one-meter square sampling areas or smaller (Greenberg 1991, Simonson 1993, Welsh and Perry 1998a, 1998b). Estimation of microhabitat variables over large geographic areas is typically cost prohibitive owing to time and laborintensive methods. Because of time and labor requirements, managers sometimes opt for collection of large scale macrohabitat data for long sections of stream habitat, although the finer scale data of microhabitats may be more appropriate to address management needs and conservation concerns. Recent advances in GIS-based data interpolation methods allow prediction (based on a small number of sampling points) of fine scale spatial habitat data across large geographic areas. Data interpolation methods are increasingly used in natural resource studies (Dettmers and Bart 1999, He et al. 2000), and should also be a useful component of stream habitat assessments.

Substrate, velocity, and depths of stream habitats are structured at larger landscape scales, such as riffle/pool sequences (Leopold and Maddock 1953, Powell 1998) and smaller scales, such as rock size sorting (Komar and Carling 1991), and velocity-controlled depositional areas with abrupt substrate transitions (Smith and Ferguson 1995, Purkait 2002). The spatially-correlated structure of stream habitats promotes highly predictable and accurate interpolations of substrate and depth data 
(Armstrong 2000). Common deterministic and geostatistical interpolation methods are available for creating models and include inverse distance weighted (IDW), spline, ordinary kriging, pointinterp, natural neighbor (NN), and trend. Trend and spline minimize curvature of the interpolated surfaces, while IDW and pointinterp assign weights to cells as a function of distance. As such, IDW and pointinterp work well when data points are (more) dense and are able to delineate clearly a complex surface. Kriging utilizes statistical interpolation and is well suited to mapping directional influence on a surface with adequate data. There are subtypes of kriging including universal, ordinary and co-kriging which are based on similar statistics but have unique strengths. Universal kriging in particular is able to address the issue of directional influence in a data set.

Natural neighbor interpolation, which we use for this study, is interpolation based on weighted values of neighboring points. Mathematically, NN interpolation uses a Theissen polygon network to calculate those values. Resulting qualities of NN interpolation include the ability to handle large numbers of input points and handle clustered (non random and spatially auto-correlated) data well. Inverse distance weight and $\mathrm{NN}$ are closely related, using similar formulas for calculations. However, NN weights spatially closer known values more heavily. The $\mathrm{NN}$ interpolation method is appropriate for stream habitat modeling because predicted values of cells are heavilyinfluenced by values of adjacent cells. In streams, habitat structuring produces differentially-sized patches of specific habitat types, so that two samples of habitat within adjacent areas of a small area are likely to be similar or spatially correlated. Spatial autocorrelation is a concern for some spatial studies (Liebhold and Gurevitch 
2002), but is an important component that contributes to predictability and accuracy in habitat interpolation methods (Robertson 1987).

Fishery managers need accurate methods of habitat measurement and mapping with fewer constraints of time, budgets, and manpower (Arnason 1990) of which map creation will be a prominent aspect (Meaden 2004). Maps of stream habitat provide fishery managers with a template for understanding abiotic and biotic components, as well as a basis for development of management options. Managers benefit from interpolated habitat maps because less data (a savings of time and labor) can achieve similar results as traditional data collection methods. The cost savings associated with interpolated data are beneficial only if the predicted data are accurate. In general, a larger sample size of initial data points will increase the accuracy of interpolated data, but the relationship between sample size and accuracy is partly controlled by habitat heterogeneity (homogeneous habitats will require fewer initial data points to achieve accurate interpolations).

The study objective was to examine the use of predictive modeling of substrate and depth in large areas of a stream channel using natural neighbor interpolation based on minimal geographic data in a GIS. Our hypothesis revolves around the inherent belief that fisheries managers need faster yet accurate methods to evaluate river habitat. Interpolation in geographic information systems is a relatively new and powerful set of methods in which the extent of modeling methodology and success is just beginning to be explored for fisheries professionals. With GIS, for the first time in our field, fisheries data and science is linked with creation of dynamic and practical maps of habitat and species for management purposes. This ability allows us to approach new time and cost saving 
options for accurate microhabitat scale habitat assessments of large sections of rivers, and provides functional maps to aid habitat-based fisheries management. Specific to this thesis, this method is being developed as an effective tool for purposes ranging from monitoring to management for the Elk River crystal darter (Crystallaria asprella ssp.), other benthic fishes, and mussels in Elk River, West Virginia.

\section{$\underline{\text { Methods }}$}

Study area

Our study site was located on a reach of 8.4 mile long Aaron Creek of the Monongahela River system in Monongalia County, West Virginia. The 2004 West Virginia Department of Environmental Protection classified the stream category 4a Impaired or threatened for one or more designated uses and TMDL has been completed (WVDEP 2004). The northwest corner of the sample site was $(591540,4386028)$ NAD 1983 UTM Zone 17 N. There is sparse to moderate suburban and business development along parts of the stream, though water quality and fish diversity remain high even with the 4a classification. Riparian area along the stream is a mixture of field, lawn and hardwood forest between $5 \mathrm{~m}$ and $50 \mathrm{~m}$ in width. Canopy cover was calculated using a densiometer at the upstream and downstream borders of the site and averaged to $25 \%$ overall. This reach was selected because it contained a complete riffle and downstream pool which appeared to contain natural characteristics of flow and sinuosity and mirrored Elk River substrate and depth attributes. The site encompassed a surface area of $210.7 \mathrm{~m}^{2}$.

An overview of the process used for this project includes data collection, georeferencing of site location, import and preparation of data in MS Excel, use of data in 
ArcMap for interpolation and modeling, and subsequent export and analysis of data

(Figure 1). The spatial scale for the measurement of stream substrate was smaller than that used for stream depth because depth was more homogenous over a given area than substrate. For the measurement of substrate, the study site was divided into a grid of 2,268 $0.093 \mathrm{~m}^{2}$ cells. The common substrate size category was recorded within each cell $(1=$ silt, $2=$ sand, $3=$ gravel, $4=$ cobble, $5=$ boulder and $0=$ land $)$ based on the Soil Survey (1993) soil sample standards (Table 1, Appendix 1). After entering the site corner locations into ArcMap, they were geo-referenced for accuracy and adjusted to match measured site size. The sample quadrant size of $0.093 \mathrm{~m}^{2}$ was smaller than our global positioning system accuracy (GPS), so adjusted site corner values were assigned (in an MS Excel spreadsheet) UTM coordinates for the center of each $0.093 \mathrm{~m}^{2}$ cell (2,268 points) using the series fill function. Performing this function allowed even distribution of $\mathrm{x}, \mathrm{y}$ coordinate points at the specified resolution and ensured that completed substrate and depth data sets were complete and accurate for import by a GIS (ArcMap 9.1). We have for this experiment located the site on the geographic plane with exact coordinates; while it is important to have the site adequately located on the geographic plane, the interpolations would be possible without an exact location so long as scale was kept the same within the GIS. In this situation, exact coordinates could be assigned later.

For measurement of depth, the site was divided into a grid of $1,1880.177 \mathrm{~m}^{2}$ cells. Depth was measured at the center of each cell using a continuous scale $(\mathrm{cm})$, and cell values were imported to a GIS (ArcMap 9.1). The 2,268 substrate values and 1,188 depth values provided complete spatial coverages of the study reach. These complete 
site coverages of substrate and depth values represented the real world site digitally (hereafter called the actual coverage, at aforementioned resolutions, of substrate or depth) and were used in accuracy assessments of interpolated values.

Interpolation of substrate and depth

The selection process of points for the $2.5 \%$ and $5 \%$ interpolations is key to successful interpolation map creation. Trial and error indicated a combination of edge boundary and feature center point selection was most effective in selecting points for our interpolations. Therefore, initial key points were selected at terminal edge boundaries, where (if on a grid placed across a stream reach) the feature ended on both the up and downstream and cross stream locations; the terminal end of a sand bar would be an example, where the bar does not continue downstream or across the location, i.e. the terminus. Once key terminus points were selected (including site corner boundaries), intermediate points were selected, in which a feature ended in two directions (up and downstream, or left and right cross stream) of which the end of a sand bar continuing downstream but having a border next to the thalweg would be an example. Once these points had been added to the layer being created for a specific $\%$ interpolation, center points of features were added showing continuation of a feature on all sides of a point (middle of a sandbar). Approximately $65 \%$ of selected points were located on intermediate and terminal boundaries, and the remaining $35 \%$ indicated center-points of features. A clustered pattern, which $\mathrm{NN}$ interpolation deals well with, is the end result of this procedure in which we sampled both $2.5 \%$ and $5 \%$ of cells from the actual coverage of substrate and depth. 
In ArcMap, 113 locations representing $0.093 \mathrm{~m}^{2}$ cells (i.e., $5 \%$ of dominant substrate composition at $0.093 \mathrm{~m}^{2}$ resolution at the $210 \mathrm{~m}^{2}$ site) was used for nearest neighbor interpolation of a new coverage of 2,268 substrate cells. Similarly, we interpolated another new coverage with a selection of 56 new cells from the same initial dataset (2.5\% of the 2,268 total cells). For depth, we interpolated two new spatial coverages with samples of $30(2.5 \%)$ and $59(5 \%)$ cells of the 1188 cells from the site at a resolution of $0.177 \mathrm{~m}^{2}$ coverage of depth data.

\section{Accuracy of interpolations}

The new data coverages of substrate and depth based on $2.5 \%$ and $5.0 \%$ interpolations were compared to values from the actual coverages. Substrate comparison was made between percent of area match for each substrate and total area for all substrates combined. Area in this case was defined by a $0.093 \mathrm{~m}^{2}$ assigned to each cell the 2268 of which make up the total study site. Thus, match percentage was also performed, assessing when true and predicted values matched exactly. The accuracy of depth interpolation was assessed based on assigned threshold values. Site depths ranged from 0 to $60 \mathrm{~cm}$, and we estimated $5 \%, 10 \%$, and 20\% threshold values which correspond to interpolated values within $3 \mathrm{~cm}, 6 \mathrm{~cm}$, and $12 \mathrm{~cm}$ of the true value. Root mean square error (RMSe) was also calculated for interpolated depth and substrate values to compare to the digital representation of our site. To calculate RMSe we first calculated standard deviation for our sample and then used the formula $\frac{\sigma}{\underline{\sqrt{n}}}$ where $\sigma=$ standard deviation of the sample and $n=$ sample size (number). Root mean square error was used because it indicates dispersion of data, and comparing dispersion levels of 
interpolations is another indicator of which interpolation matches best with the digital representation of our study site's depth and substrate values.

\section{$\underline{\text { Results }}$}

Habitat Mapping

Raster maps of interpolated values of substrate and depth depicted close approximations to the study reach maps of true values (Figure 2 and 3). The raster map interpolated from the 5\% sample more closely mirrors measured reality in structure and location of substrates and edge boundaries than the $2.5 \%$ interpolation (Figure 2). Similarly, the raster map interpolated from 5\% of depth samples provided a more accurate representation of shape and overall depth structure of the study site than that from the $2.5 \%$ sample (Figure 3).

\section{Substrate Interpolation}

Based on the exact match between actual and interpolated substrate cells, the $5 \%$ and $2.5 \%$ samples correctly interpolated cell substrate categories on 61 and 46 percent of the total cells, respectively (Figure 4). Based on the percent area match between actual and interpolated substrate cells, the $5 \%$ and $2.5 \%$ samples correctly interpolated cell substrate categories on $79 \%$ and $54 \%$ of the total cells, respectively (Figure 4). When substrate categories were considered separately, less than a 5\% difference in area occurred between actual cells and those interpolated from the 5\% sample, with the exception of silt (Figure 5). Further, based on the $2.5 \%$ sample, a similar accuracy of less than $5 \%$ occurred for land, cobble, and sand categories, but differences were larger for silt (11\%), gravel (15\%), and boulder (19.5\%; Figure 5). Root mean square error values for substrate supported our percent accuracy levels, showing that interpolated 
values closer in dispersion (RMSe value) to actual values had higher accuracy levels

(Table 2). Sand interpolation, which was most accurate, most closely matched actual RMSe values (Table 2).

Depth Interpolation

Depth data were interpolated with a sample of $2.5 \%$ and $5 \%$ of the total number of depth cells. Accuracy of depth interpolations was assessed with the percent of interpolated values within several ranges of actual values based on thresholds of 5, 10, and $20 \%$ of the maximum site depth of $60 \mathrm{~cm}$ (Figure 6). Based on interpolation from $5 \%$ of the depth measurements (59 data points), $57.3 \%$ of the interpolated depths were within a $5 \%$ threshold $(3 \mathrm{~cm})$ of the actual values, $82.7 \%$ percent within $10 \%(6 \mathrm{~cm})$, and $95.1 \%$ of all depth values were within $20 \%(12 \mathrm{~cm})$ of actual values (Figure 6$)$. A lower accuracy occurred for interpolated values from $2.5 \%$ of depth measurements; $49 \%$ of values were within a $5 \%$ threshold $(3 \mathrm{~cm}=5 \%$ of maximum depth at site $)$ of the actual depth values, $71 \%$ of interpolated values were within $6 \mathrm{~cm}$ of actual values, and $92.8 \%$ were within $12 \mathrm{~cm}$ of actual values (Figure 6). RMSe values reflected percent accuracy levels, and indicated that the 5\% depth interpolation was closer in dispersion levels than the $2.5 \%$ interpolation (Table 3 ).

\section{$\underline{\text { Discussion }}$}

Given the importance of habitat to the management and conservation of fishes (Noss et al. 1997, Orth and White 1999, Kohler and Hubert 1999, Thayer 1996), methods are needed for accurate, and cost-effective habitat sampling. Further, the technology to convert habitat data into accurate and usable habitat maps is an increasingly important benefit for aquatic species management (Kostylev et al 2001, 
Manson and Todd 2000, Smith and Greenhawk 1998, Meaden and Do Chi 1996, Fisher and Rahel 2004). Our findings support a need for habitat interpolation methods in aquatic management and conservation programs, because a relatively small amount of data at fine spatial scales can be used in interpolation of fine scale data across larger habitat areas. This high accuracy of interpolated values and habitat predictability is possible owing to the spatially-correlated and structured features of stream habitats (Powell 1998, Rubec et al 1998, Jeffrey and Edds 1997, Bain et al. 1999,Ferguson 2003, Knighton 1998, Lisle 1979, Keller 1971, Leopold and Wolman 1957). This method provides fishery managers with accurate habitat assessments and habitat mapping with low constraints of time, budgets, and manpower.

Habitat assessments of long stream sections either focus on large area management objectives or accommodate cost constraints through avoidance of time and labor-intensive efforts of smaller scale data. Habitat assessments often focus on large areas, such as watersheds or stream reaches, but may also require fine-scale microhabitat data to address management needs and conservation concerns. Data interpolation methods can predict fine-scale spatial habitat data across large geographic areas, because habitat across large areas can be interpolated from data collected at a small number of sampling points (King et al. 1991, Rastetter et al. 1992). This approach allows interpretation of small scale (microhabitat) data over large geographic areas, and allows rasterized-data of microhabitats to be combined into larger scale habitat assessments. Conversely, data initially collected at large spatial scales are not easily or accurately scaled down to smaller areas (McPherson et al. 2006). 
Spatial autocorrelation is a well-documented concern for geospatial studies (Henebry and Merchant 2002, Liebhold and Gurevitch 2002), but is an important component that contributes to predictability and accuracy in some ecological mapping and prediction methods (Klute et al. 2002, Rotenberry et al. 2002), including habitat interpolation methods (Robertson 1987). In stream habitats, proximate areas are more similar than distant areas, particularly with common stream characteristics of substrate, velocity, and depth (Leopold and Maddock 1953, Powell 1998). The nearest-neighbor interpolation method accurately predicted stream depth and substrate using small amounts of data.

This habitat interpolation method provides fishery managers with accurate habitat measurement and mapping with fewer constraints of time, budgets, and manpower (Arnason 1990). With this interpolation method, small amounts of data (a savings of time and labor) achieve similar results to large-scale time and labor intensive sampling efforts. The accuracy afforded by interpolation further promotes the costsavings associated with interpolated data. Accuracy of this approach however is tied to habitat complexity and the spatial scale of data collection. Heterogeneous habitats will require a larger number of sampling points to achieve higher levels of accuracy; however, management decisions are often possible with low-resolution geospatial data or close approximations of the parameters of interest, such as habitat categories.

Although we examined accuracy of interpolated data based on initial $2.5 \%$ and $5 \%$ samples, accuracy is expected to improve with an increase in the initial sample size, and may also improve with a single analysis of combined data, such as interpolation with cokriging of multiple habitat characters. Further research should examine the threshold scale 
that relates sample size with accuracy (Host et al. 1995, Winkler and Fang 1997), and the related cost-benefit function that accompanies an increasing sample size. This relationship is also expected to differ with habitat complexity, and interpolation of stream habitat within pools would likely require a smaller initial sample size than interpolation of riffle habitats. At a larger scale of interest, interpolation of habitat for a stream section with a large pool/riffle ratio would likely require a smaller sample size relative to one with a complex high gradient profile (Keim and Skaugset 2002). Further analysis of interpolation with universal kriging and co-kriging, which both allow more directional influence to be accounted for in a data set (important to streams) may also allow improved accuracy with a smaller initial sample size.

A further extension of habitat interpolation methods includes the use of interpolated maps with prediction of species occurrence. Stream maps from interpolated data of substrate, depth, and velocity will allow prediction of species occurrence based on existing knowledge of species requirements for these habitat variables. This use of interpolated maps will benefit rare-species management, when habitat loss or habitatspecificity is an important management concern, such as in some benthic fishes or

freshwater mussels. Our further research will focus this approach on the Elk River, West Virginia, and on habitat availability and prediction of occurrence of the Elk River crystal darter.

\section{Acknowledgements}

This study was funded by the United States Fish and Wildlife Service. We thank P. Mazik, J. S. Kite, G. Staines and R. Utz for comments and criticisms during creation of the 
manuscript and during the scientific process. Reference to trade names does not imply government endorsement of commercial products.

\section{Literature Cited}

Arend, K. K. 1999. Classification of streams and reaches. Pages 57-74 in M. B. Bain and N. J. Stevenson, editors. Aquatic habitat assessment: common methods. American Fisheries Society, Bethesda, Maryland.

Armstrong, M. P. 2000. Geography and computational science. Annals of the Association of American Geographers 90:146-156.

Arnason, R. 1990. Minimum information management in fisheries. The Canadian Journal of Economics / Revue Canadienne d'Economique 23: 630-653.

Atkinson, P. M. 1996. Optimal sampling strategies for raster-based geographical information systems. Global Ecology and Biogeography Letters 5:271-280.

Bain, M. B., T. C. Hughes, and K. K. Arend. 1999. Trends in methods for assessing freshwater habitats. Fisheries 24:16-21.

Bain, M. B. and N. J. Stevenenson, editors. 1999. Aquatic habitat assessment: common methods. American Fisheries Society, Bethesda, Maryland.

Dettmers, R. and J. Bart. 1999. A GIS modeling method applied to predicting forest songbird habitat. Ecological Applications 9:152-163.

Ferguson, R.I. 2003. Emergence of abrupt gravel to sand transitions along rivers through sorting processes. Geological Society of America 31(2):159-162.

Fisher, W. L. and F. J. Rahel, editors. 2004. Geographic information systems in fisheries. American Fisheries Society, Bethesda, Maryland.

Gorman, O. T. and J. R. Karr. 1978. Habitat structure and stream fish communities. Ecology 59: 507-515.

Greenberg, L. A. 1991. Habitat use and feeding behavior of thirteen species of benthic stream fishes. Environmental Biology of Fishes 31:389-401.

He, H. S., D. J. Madenoff, T. A. Sickley, and G. G. Guntenspergen. 2000. GIS interpolations of witness tree records (1839-1866) for northern Wisconsin at multiple scales. Journal of Biogeography 27:1031-1042. 
Henebry, G. M. and J. W. Merchant. 2002. Geospatial data in time: limits and prospects for protecting species occurrences. Pages 291-302 in J.M. Scott, P.J. Heglund, and M.L. Morrison, editors. Predicting species occurrences: issues of accuracy and scale. Island Press, Washington, DC.

Host, G., H. Omre, and P. Switzer. 1995. Spatial interpolation errors for monitoring data. Journal of the American Statistical Association 90:853-861.

Jeffrey, J. D. and D. R. Edds. 1997. A global positioning system for aquatic surveys. Fisheries 22:16-20.

Keller, E. A. 1971. Areal sorting of bed load material: the hypothesis of velocity reversal. Bulletin of the Geological Society of America. 82:753-756.

Kiem, R. F. and A. E. Skauset. 2002. Physical aquatic habitat errors associated with measurement and estimation of residual pool volumes. North American Journal of Fisheries Management 22:145-150.

King, A. W., A. R. Johnson, and R. V. O’Neill. 1991. Transmutation and functional representation of heterogeneous landscapes. Landscape Ecology 5:239-253.

Klute, D. S., M. J. Lovallo, and W. M. Tzilkowski. 2002. Autologistic regression modeling of American woodcock habitat use with spatially dependent data. Pages 335-344 in J. M. Scott, P. J. Heglund, and M. L. Morrison, editors. Predicting species occurrences: issues of accuracy and scale. Island Press, Washington, DC.

Knighton, D. 1998. Fluvial forms and processes: a new perspective. Oxford University Press, Great Britain.

Kohler, C. C. and W. A. Hubert, editors. 1999. Inland fisheries management in North America. American Fisheries Society, Bethesda, Maryland.

Komar, P. D. and P. A. Carling. 1991. Grain sorting in gravel-bed streams and the choices of particle sizes for flow-competence evaluations. Sedimentology $38: 489-502$

Kostylev, V. E., B. J. Todd, G. B. J. Fader, R. C. Courtney, G. D. M. Cameron, and R. A. Pickrill. 2001. Benthic habitat mapping on the Scotian Shelf based on multibeam bathymetry, surficial geology and sea floor photographs. Marine Ecology Progress Series 219:121-137. 
Leopold, L. B. and T. Maddock. 1953. The hydraulic geometry of stream channels and some physiographic implications. Unites States Geological Survey Professional Paper 252, $57 \mathrm{pp}$.

Leopold, L. B. and M. G. Wolman. 1957. River channel patterns- braided, meandering and straight. United States Geological Survey Professional Paper 282A.

Liebhold, A. M. and J. Gurevitch. 2002. Integrating the statistical analysis of spatial data in ecology. Ecography 25: 553-557.

Manson, G. and B. J. Todd. 2000. Revolution in the Nova Scotia scallop fishery: seabed maps turn hunting into harvesting. Fishing News International 39:20-22.

McPherson, J. M., W. Jetz, and D. J. Rogers. 2006. Using coarse-grained occurrence data to predict species distributions at finer spatial resolutions - possibilities and limitations. Ecological Modeling 192:499-522.

Meaden, G.J. 2004. Challenges of using geographic information systems in aquatic environments in Fisher, W. L. and F. J. Rahel, editors. Geographic information systems in fisheries. American Fisheries Society, Bethesda, Maryland.

Meaden, G. J. and T. Do Chi. 1996. Geographical information systems: applications to marine fisheries. FAO Fisheries Technical Paper. No. 356. Rome, FAO.

Murphy, B. R., and D. W. Willis, editors. 1999. Fisheries techniques; Second Edition. American Fisheries Society, Bethesda Maryland.

Noss, R. F., M. O’Connel, D. D. Murphy. 1997. The science of conservation planning: habitat conservation under the Endangered Species Act. Island Press, Washington D.C.

Orth, D. J., and R. J. White. 1999. Stream habitat management. Pages 249-284 in Kohler C.C. and W. A. Hubert, editors. Inland Fisheries Management in North America. American Fisheries Society, Bethesda, Maryland.

Powell, D. M. 1998. Patterns and processes of sediment sorting in gravel-bed rivers. Progress in Physical Geography 22:1-32.

Purkait, B. 2002. Patterns of grain-size distribution in some point bars of the USRI River, India. Journal of Sedimentary Research. 72:367-375. 
Rastetter, E. B., A. W. King, B. J. Cosby, G. M. Hornberger, R. V. O’Neill, and J. E. Hobbie. 1992. Aggregating fine-scale ecological knowledge to model coarsescale attributes of ecosystems. Ecological Applications 2:55-70.

Robertson, G. P. 1987. Geostatistics in ecology: interpolating with known variance. Ecology 68:744-748.

Rose, K. A. 2000. Why are quantitative relationships between environmental quality and fish populations so elusive? Ecological Applications 10:367-385.

Rosgen, D. 1996. Applied river morphology. Wildland Hydrology, Pagosa Springs, Colorado.

Rotenberry, J. T., S. T. Knick, and J. E. Dunn. 2002. A minimalist approach to mapping species' habitat: Pearson's planes of closest fit. Pages 281-290 in J. M. Scott, P. J. Heglund, and M. L. Morrison, editors. Predicting species occurrences: issues of accuracy and scale. Island Press, Washington, DC.

Rubec, P. J., M. S. Coyne, R. H. McMichael, and M. E. Monaco. 1998. Spatial methods being developed in Florida to determine essential fish habitat. Fisheries 23:2125.

Simonson, T. D. 1993. Correspondence and relative precision of stream habitat features estimated at two spatial scales. Journal of Freshwater Ecology 8:363-373.

Smith, G. F., and K. N. Greenhawk. 1998. Shellfish benthic habitat assessment in the Chesapeake Bay: progress toward integrated technologies for mapping and analysis. Journal of Shellfish Research 17:1433-1437.

Smith, G. H. and R. I. Ferguson. 1995. The gravel-sand transition along river channels. Journal of Sedimentary Research A65: 423-430.

Soil Survey Division Staff. 1993. Soil survey manual. Soil Conservation Service. U.S. Department of Agriculture Handbook 18.

Thayer, G. W., J. P. Thomas, and K. V. Koski. 1996. The habitat research plan of the National Marine Fisheries Service. Fisheries 21:6-10.

Vine, M. F., D. Degnan, and C. Hanchette. 1997. Geographic information systems: their use in environmental epidemiologic research. Environmental Health Perspectives 105:598-605. 
Welsh, S. A., and S. A. Perry. 1998a. Habitat partitioning in a community of darters in the Elk River, West Virginia. Environmental Biology of Fishes 51:411-419.

Welsh, S. A., and S. A. Perry. 1998b. Influence of spatial scale on estimates of substrate use by benthic darters. North American Journal of Fisheries Management 18: 954-959.

Winkler, P., and K. T. Fang. 1997. Application of threshold-accepting to the evaluation of the discrepancy of a set of points. SIAM Journal on Numerical Analysis 34:2028-2042. 
Table 1. Substrate size categories of the United States Department of Agriculture (Soil Survey Division Staff 1993).

Substrate Name

Diameter in millimeters

\begin{tabular}{ll}
\hline Stones & $>250$ \\
Cobble & $250-76$ \\
Gravel & $76-2$ \\
Very coarse sand & $2-1$ \\
Coarse sand & $1-0.5$ \\
Medium sand & $0.5-0.25$ \\
Fine sand & $0.25-0.10$ \\
Very fine sand & $0.10-0.005$ \\
Coarse silt & $0.005-0.002$ \\
\hline
\end{tabular}


Table 2. Substrate root mean square error values of complete substrate based on actual values, $5 \%$ interpolation and individual 5\% substrate type root mean square error values.

\begin{tabular}{ll}
\hline RMSe & \\
Value & SUBSTRATE \\
\hline 0.074 & Gravel \\
0.049 & Silt \\
0.046 & Boulder \\
0.039 & All Substrate (actual) \\
0.034 & Sand \\
0.033 & Cobble \\
0.030 & 5\% Interpolation \\
0.028 & Land \\
\hline
\end{tabular}


Table 3. Depth root mean square error values based on actual values, 5\% interpolation, and $2.5 \%$ interpolation.

\begin{tabular}{ll}
\hline RMSe & DEPTH \\
\hline 0.38533 & Complete Depth (Actual) \\
0.36623 & $5 \%$ Interpolation \\
0.34491 & $2.5 \%$ Interpolation \\
\hline
\end{tabular}




\section{List of Figures}

Figure 1. Simple flow chart containing general overview of data collection and interpolation process.

Figure 2. Raster maps of substrate at the Aarons Creek study site for actual substrate values (Actual), and interpolated values based on 5\% (A) and 2.5\% (B) of actual values. Northwest corner of actual and interpolations $\mathrm{A} / \mathrm{B}=(591540,4386028)$.

Figure 3. Raster maps of water depth at the Aarons Creek study site for actual depth values (Actual), and interpolated values based on 5\% (A) and 2.5\% (B) of actual values. Northwest corner of Actual/A/B = $(591540,4386028)$.

Figure 4. Two methods of accuracy assessments of $2.5 \%$ and $5.0 \%$ substrate interpolations; (1) the percent match of interpolated and actual cell values of substrate types and (2) the percent match of interpolated and actual areas of substrate types.

Figure 5. The percent difference between interpolated and actual substrate areas for six substrate categories. Interpolation A is based on 5\% of actual substrate cell values and interpolation B is based on $2.5 \%$ of actual substrate cell values.

Figure 6. Accuracy assessment of the 5\% (A) and 2.5\% (B) depth interpolations using the percent of interpolated values within several ranges of true values based on thresholds of $5 \%(3 \mathrm{~cm}), 10 \%(6 \mathrm{~cm})$, and $20 \%(12 \mathrm{~cm})$ of maximum site depth $(60 \mathrm{~cm})$. 
Figures

Data collection at site substrate/depth, site characteristics, UTM coordinates

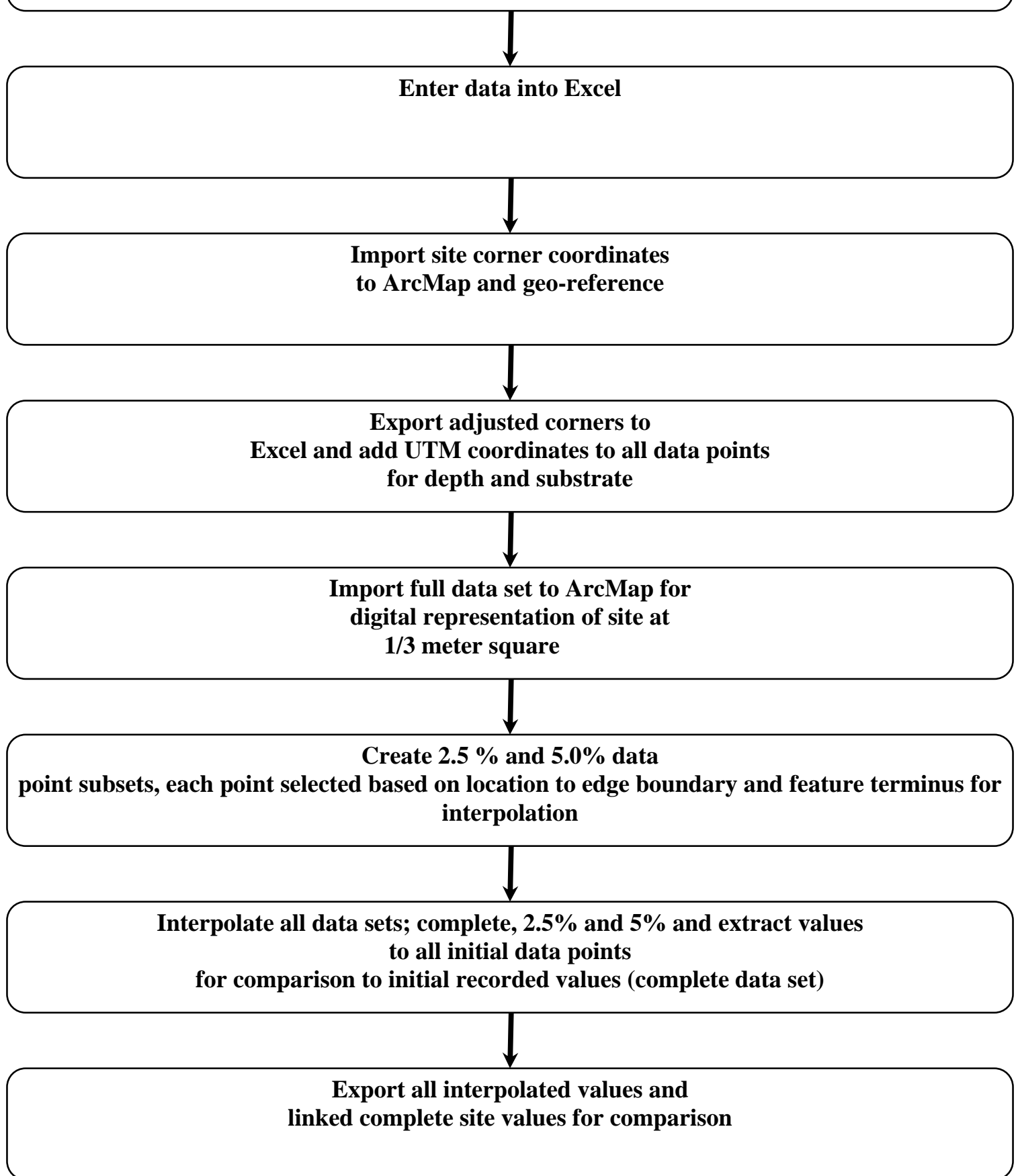

Figure 1. Simple flow chart containing general overview of data collection and interpolation process. 


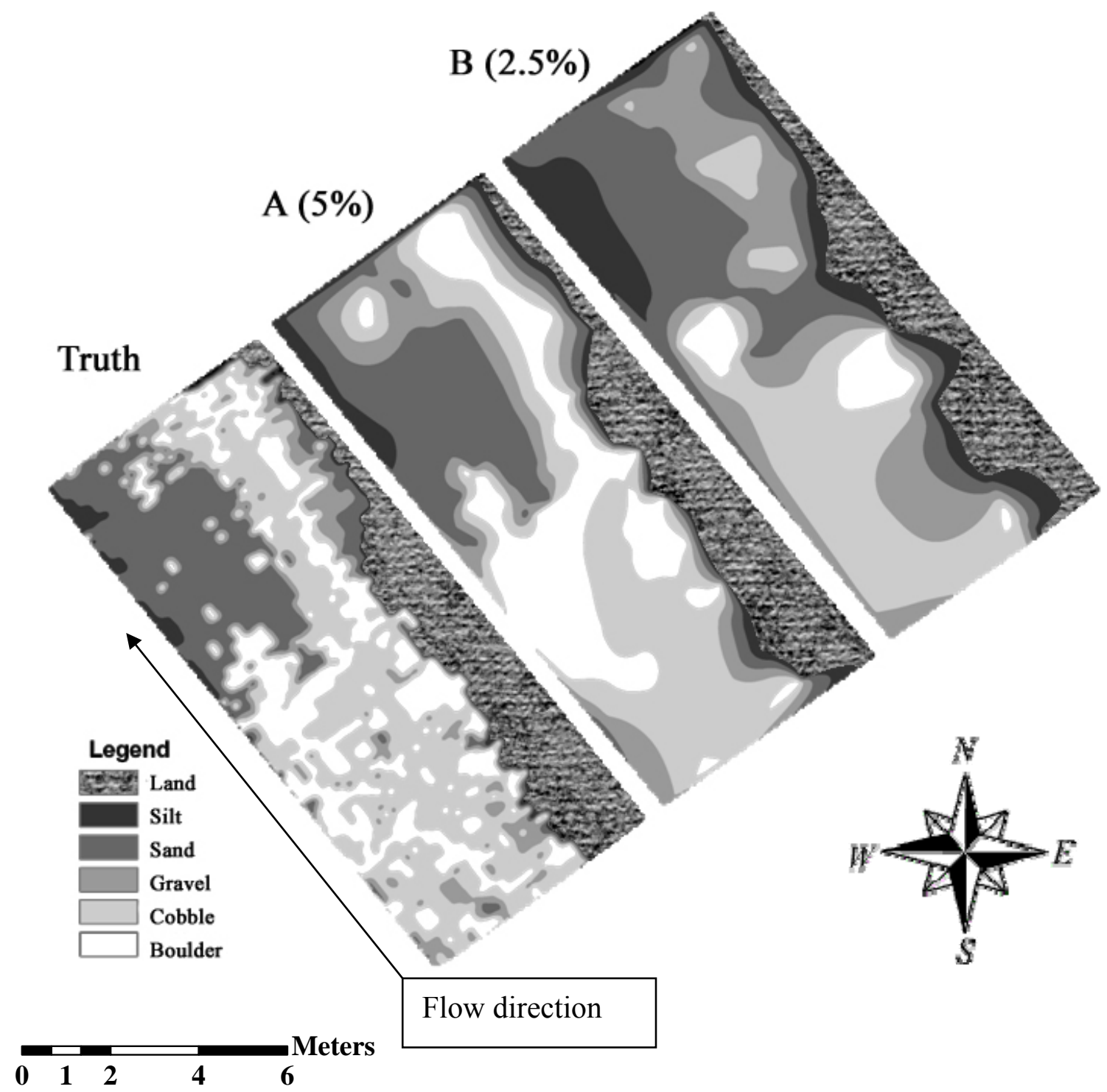

Figure 2. Raster maps of substrate at the Aarons Creek study site for actual substrate values (Actual), and interpolated values based on 5\% (A) and 2.5\% (B) of actual values. Northwest corner of actual and interpolations $A / B=(591540,4386028)$. 


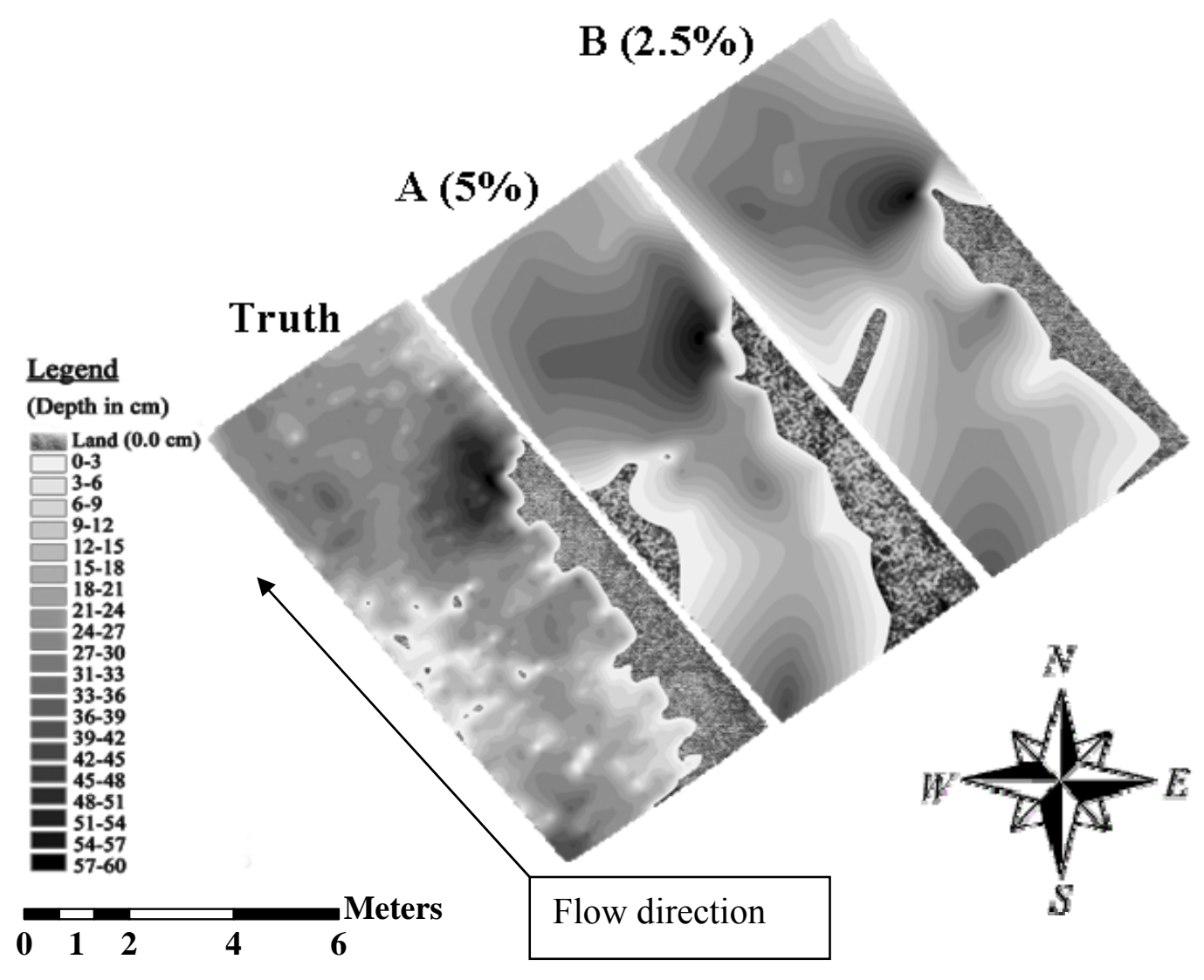

Figure 3. Raster maps of water depth at the Aarons Creek study site for actual depth values (Actual), and interpolated values based on 5\% (A) and 2.5\% (B) of actual values. Northwest corner of Actual/A/B $=(591540,4386028)$. 


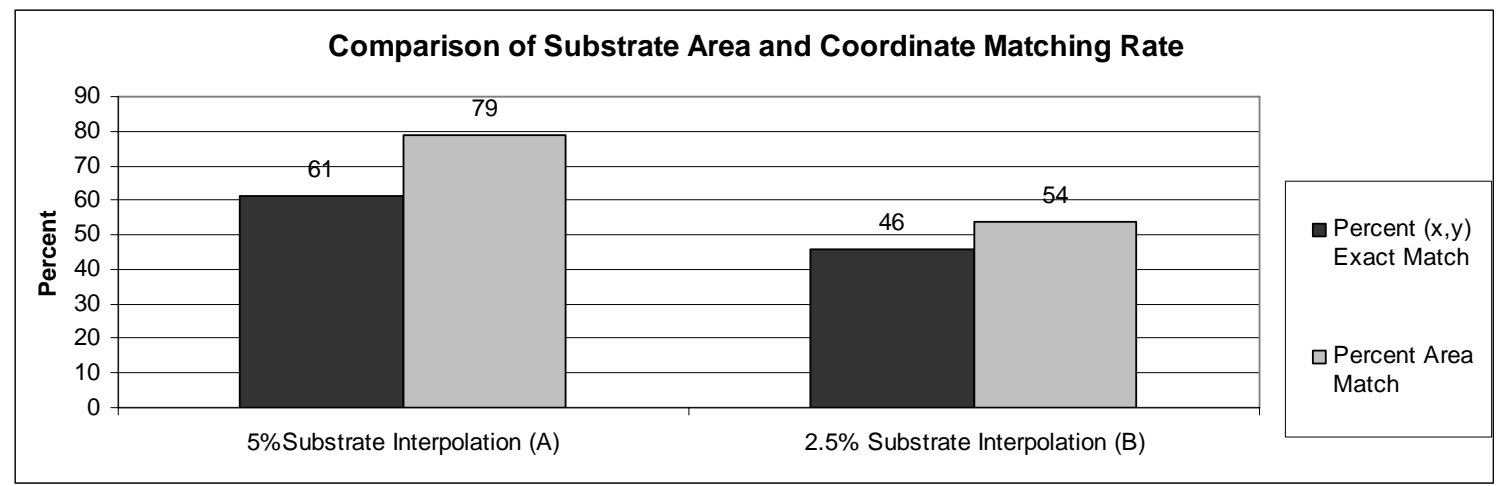

Figure 4. Two methods of accuracy assessments of $2.5 \%$ and $5.0 \%$ substrate interpolations; (1) the percent match of interpolated and actual cell values of substrate types and (2) the percent match of interpolated and actual areas of substrate types. 


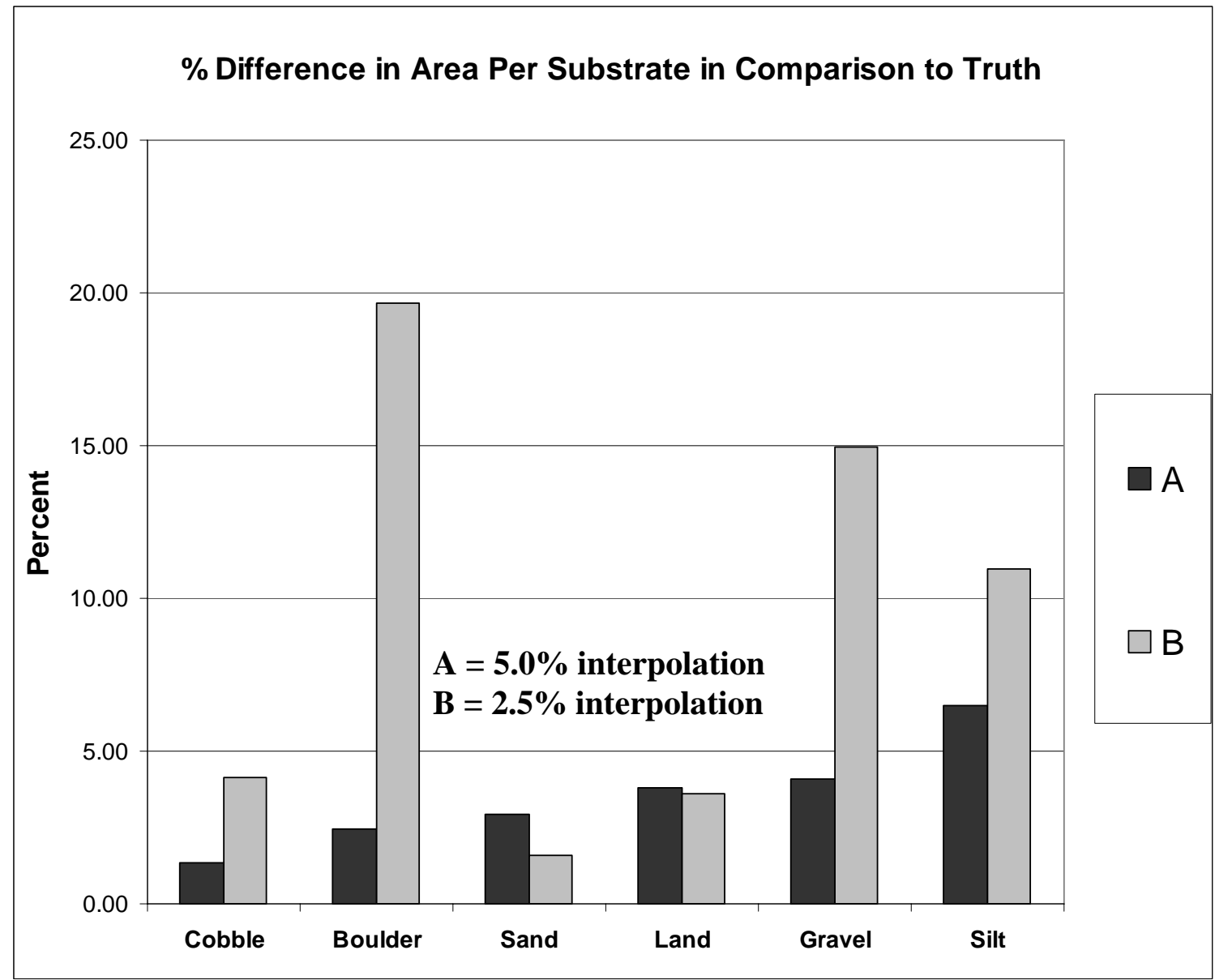

Figure 5. The percent difference between interpolated and actual substrate areas for six substrate categories. Interpolation $\mathrm{A}$ is based on $5 \%$ of actual substrate cell values and interpolation B is based on $2.5 \%$ of actual substrate cell values. 


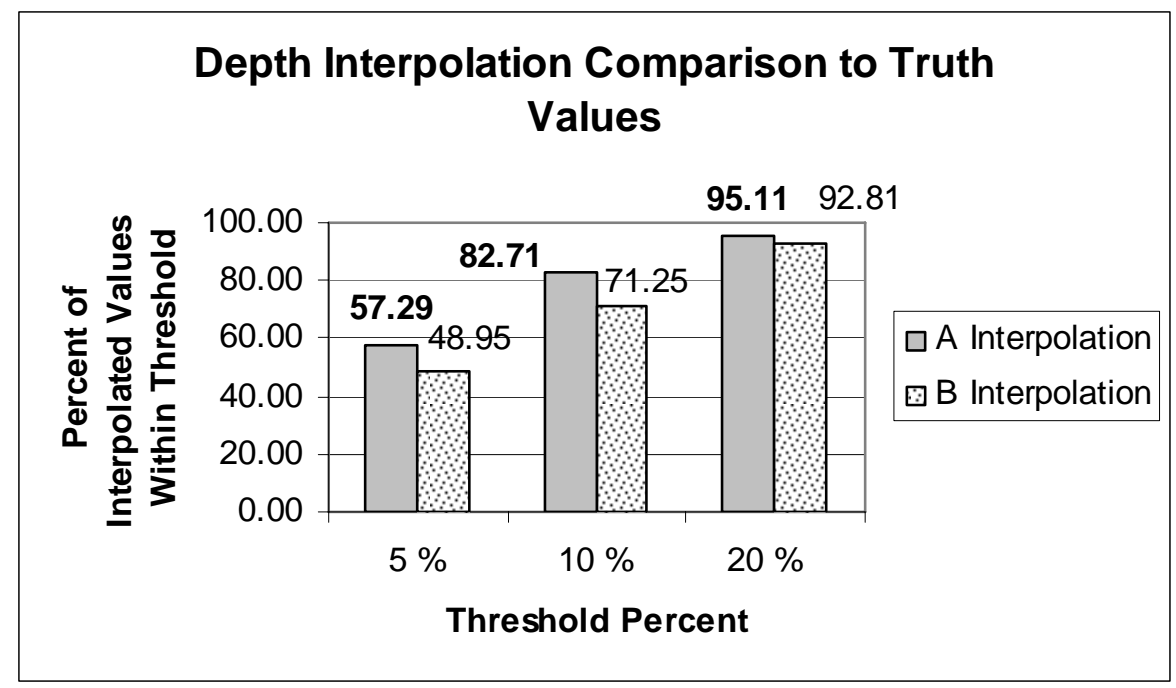

Figure 6. Accuracy assessment of the 5\% (A) and 2.5\% (B) depth interpolations using the percent of interpolated values within several ranges of true values based on thresholds of $5 \%(3 \mathrm{~cm}), 10 \%(6 \mathrm{~cm})$, and $20 \%(12 \mathrm{~cm})$ of maximum site depth $(60 \mathrm{~cm})$. 


\section{Appendix}

Appendix 1. A PVC grid $\left(0.093 \mathrm{~m}^{2}\right)$ used for substrate sampling.

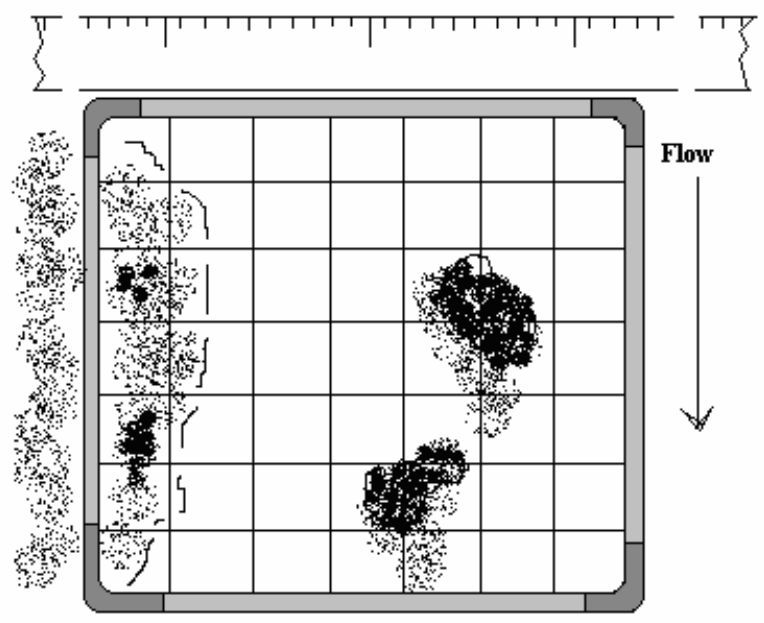

